\title{
Antifouling Activities against Colonizer Marine Bacteria of Extracts from Marine Invertebrates Collected in the Colombian Caribbean Sea and on the Brazilian Coast (Santa Catarina)
}

\author{
Jennyfer A. Mora-Cristancho ${ }^{\mathrm{a}}$, Catalina Arévalo-Ferro ${ }^{\mathrm{a}}$, Freddy A. Ramos ${ }^{\mathrm{b}, *}$, \\ Edisson Tello ${ }^{\mathrm{b}}$, Carmenza Duque ${ }^{\mathrm{b}}$, Cintia Lhullier ${ }^{\mathrm{c}}$, Miriam Falkenberg ${ }^{\mathrm{c}}$, \\ and Eloir Paulo Schenkel ${ }^{\mathrm{c}}$ \\ a Departamento de Biología, Universidad Nacional de Colombia, Bogotá, Colombia \\ b Departamento de Química, Universidad Nacional de Colombia, Bogotá, Colombia. \\ Fax: (57+1+3165220). E-mail: faramos@unal.edu.co \\ c Departamento de Ciencias Farmaceúticas, Universidade Federal de Santa Catarina, \\ Florianópolis, SC, Brazil \\ * Author for correspondence and reprint requests \\ Z. Naturforsch. 66 c, 515-526 (2011); received December 10, 2010/June 28, 2011
}

The growth inhibition of 12 native marine bacteria isolated from Aplysina sponge surfaces, the shell of a bivalve, and Phytagel ${ }^{\mathrm{TM}}$ immersed for $48 \mathrm{~h}$ in sea water were used as indicator of the antifouling activity of the extracts of 39 marine organisms (octocorals, sponges, algae, and zoanthid) collected in the Colombian Caribbean Sea and on the Brazilian coast (Santa Catarina). Gram-negative bacteria represented $75 \%$ of the isolates; identified strains belonged to Oceanobacillus iheyensis, Ochrobactrum pseudogrignonense, Vibrio campbellii, Vibrio harveyi, and Bacillus megaterium species and seven strains were classified at genus level by the $16 \mathrm{~S}$ rRNA sequencing method. The extracts of the octocorals Pseudopterogorgia elisabethae, four Eunicea octocorals, and the sponges Topsentia ophiraphidites, Agelas citrina, Neopetrosia carbonaria, Monanchora arbuscula, Cliona tenuis, Iotrochota imminuta, and Ptilocaulis walpersii were the most active, thus suggesting those species as antifoulant producers. This is the first study of natural antifoulants from marine organisms collected on the Colombian and Brazilian coasts.

Key words: Antifouling Activity, Antibacterial Activity, Marine Invertebrate-Associated Bacteria, 16S rRNA Gene Analysis

\section{Introduction}

Fouling organisms, mainly consisting of microbial slimes, diatoms, barnacles, tunicates, bryozoans, and spores of algae, cause extensive damage to commercial important man-made structures exposed to sea water, by forming a complex layer on their surfaces as a result of adhesion of marine organisms (Fusetani, 2004). This phenomenon known as biofouling is viewed as a serious economic problem estimated to be about $\$ 5$ billion/year considering only the shipping industry (Fusetani and Clare, 2006). For many years, different antifouling technologies have been developed with the result that the only solution of the problem is to cover exposed surfaces with paints based on copper or tin compounds, which kill the fouling organisms by a continuous release of organometallic compounds to the surrounding sea water (Yebra et al., 2004). However, the adverse effect of those organometallic compounds, such as toxicity and other harmful effects (i.e. imposex) on non-target organisms, is well recognized up to a point where the use of these paints has been banned in many countries (Fusetani and Clare, 2006). Recently, as an alternative to toxic compounds, the use of natural products present in marine organisms, which might be toxic but biodegradable, turns into an interesting option to incorporate them into environmentally friendly antifouling paints. Those antifouling compounds could be isolated from sessile marine animals free from fouling which produce such compounds presumably as a means of protection from predation or fouling or to reduce competition for space. Some of the studied organisms are sponges, algae, and bryozoans, in which terpenoid isocyano compounds, 3-alkylpyridinium compounds, brominated furanones, and brominated indole alkaloids have been found as secondary metabolites which can control the colonization of fouling organisms (Fusetani, 2004, 2011). 
The first step in the development of natural products as commercial antifoulants is the evaluation of the antifouling potential of the source. A broad selection of marine organisms has been used as a model for antifouling bioassays including barnacles, macroalgae, bivalves, marine fungi, and bacteria, attempting to cover a wide selection of the most common colonizer organisms in different geographical conditions (Briand, 2009). It has been established that bacteria are the first organisms to colonize immersed surfaces (Krug, 2006). They associate with soft-bodied organisms or with inert surfaces and form biofilms which have long been recognized as fundamental settlement cues (positive or negative stimuli) for the attachment and growth of other organisms such as other bacteria, invertebrate larvae or spores of algae (Dobretsov and Qian, 2004). Thus, the bacterial community is often involved in the process of fouling by regulating the settlement of organisms and by promoting or inhibiting colonization (Dobretsov and Qian, 2004; Qian et al., 2007; Briand, 2009).

According to the above mentioned considerations and as part of our continuous search for useful compounds from marine organisms collected in the Colombian Caribbean Sea (Duque et al., 2006; Tello et al., 2009; Correa et al., 2009) and on the Brazilian coast (Lhullier et al., 2010), we isolated and identified 12 marine bacterial strains associated with immersed fouled surfaces and used them to test the antibacterial activity of 39 extracts from clean surfaces of marine organisms as a first approach to evaluate the presence of antifouling compounds in these extracts.

\section{Methods}

\section{Isolation of marine surface colonizer bacteria}

Marine bacteria were obtained from the external pinacoderm and from the grooves formed by the intake pores (ostium) of Aplysina lacunosa pinacoderm (strains 3-7 and 12), from the external pinacoderm of Aplysina insularis (strains 8 and 9), from the calcareous surface of the abandoned shell of Donax sp. (strains 1 and 2), and from Phytagel $^{\mathrm{TM}}$ immersed in sea water for $48 \mathrm{~h}$ (strains 10 and 11). The organisms were collected using scuba diving at depths of 5-15 $\mathrm{m}$ at the Granate Ensenada (Tayrona Natural National Park, North of the Colombian Caribbean). The bacteria were isolated from the sponges as follows. Surface fragments of the sponges were cut underwater (approx. $1 \mathrm{~cm}^{2}$ each), using gloves and sterile scalpels, and taken immediately to the laboratory in sterile Whirl-Pack ${ }^{\circledR}$ bags. Each sponge sample was then rinsed three times in sterile sea water. Bacteria were obtained swabbing the external surface of each fragment with a sterile cotton swab and were then placed in $5 \mathrm{~mL}$ of sterile sea water and vortexed. Serial 6-fold dilutions of each solution were prepared and aliquots $(0.1 \mathrm{~mL})$ were plated on glycerol artificial seawater medium (GASW) (Smith and Hayasaka, 1982; Mora-Cristancho et al., 2008) in two replicates. Plates were incubated for $8 \mathrm{~d}$ at room temperature $\left[(25 \pm 3){ }^{\circ} \mathrm{C}\right]$. Isolation of bacteria from Phytagel ${ }^{\mathrm{TM}}$ gels was performed as follows. Phytagel ${ }^{\mathrm{TM}}(0.53 \mathrm{~g})$ was added to $50 \mathrm{~mL}$ distilled water. The gel mixture was heated until boiling and poured into $10-\mathrm{cm}$ diameter Petri plates following the method of Henrikson and Pawlik (1995). Four Petri plates were placed $2 \mathrm{~m}$ below the water surface in Santa Marta Bay for $48 \mathrm{~h}$, and the bacteria were obtained by swabbing the surface of these gels.

All cultured isolates were selected by colony morphological characteristics and purified by repeated single colony subculture in the same media. These were also kept in slant cultures at $4{ }^{\circ} \mathrm{C}$ and at room temperature.

\section{Identification of bacterial strains}

DNA extraction and 16S rDNA sequencing

DNA was extracted using standard phenol/chloroform extraction procedures. Polymerase chain reaction (PCR) amplification was performed in a total volume of $50 \mu \mathrm{L}$ containing $1 \mathrm{X}$ PCR buffer [20 mm Tris- $\mathrm{HCl}(\mathrm{pH} 8.4), 50 \mathrm{~mm} \mathrm{KCl}], 200 \mu \mathrm{M}$ of each deoxynucleotide, $1.5 \mathrm{~mm} \mathrm{MgCl}_{2}, 2.5 \mathrm{U}$ Taq DNA polymerase (Invitrogen TM, Carlsbad, CA, USA), 50 ng DNA, and the universal primers 27F (5'-AGAGTTTGATCMTGGCTCAG-3') and 1492R (5'-TACGGYTACCTTGTTACGACTT-3') (Lane, 1991). PCR conditions were as follows: initial denaturation for $2 \mathrm{~min}$ at $95^{\circ} \mathrm{C}$, followed by 30 cycles of denaturation for $1 \mathrm{~min}$ at $95^{\circ} \mathrm{C}$, primer annealing for $1 \mathrm{~min}$ at $56^{\circ} \mathrm{C}$, and primer extension for $1.3 \mathrm{~min}$ at $72^{\circ} \mathrm{C}$ with a cycle of final extension for $10 \mathrm{~min}$ at $72{ }^{\circ} \mathrm{C}$. The PCR amplification product was purified and sequenced using the sequencing services of Macrogen (Seoul, Korea). 
Sequence analyses

Each sequence was defined as an operational taxonomic unit (OTU). Sequences were assembled in the CAP3 DNA sequence assembly program (Huang and Madan, 1999) and subsequently aligned using the software Clustal X v.2.0.10 (Larkin et al., 2007). A dendogram was constructed using the neighbour-joining algorithm (Saitou and Nei, 1987) and Kimura two-parameter method (Kimura, 1980) and processed using MEGA software (Tamura et al., 2007). The robustness of the inferred tree topology was evaluated with 1000 bootstrap replicates.

\section{Nucleotide sequence accession numbers}

The GenBank accession numbers for the sequences generated in this study are GQ203107 through GQ203118.

\section{Evaluation of antifouling activity of marine invertebrate extracts}

\section{Preparation of extracts}

The 33 marine invertebrates were collected at the Santa Marta Bay and at the Rosario Islands, Colombia, by means of scuba diving, between September 2005 and March 2006. The samples included the soft corals Eunicea knighti, Eunicea succinea, Eunicea fusca, Eunicea sp. 2, Eunicea tayrona, Eunicea laciniata, Muriceopsis sp., Erythropodium caribaeorum and two chemotypes of Pseudopterogorgia elisabethae (chemotype 1 and chemotype 2); the sponges Biemna cribaria, Iotrochota imminuta, Dragmacidon reticulata, Oceanapia peltata, Cinachyrella kuekenthali, Spirastrella coccinea, Cliona tenuis, Cliona delitrix, Agelas conifera, Agelas citrina, Monanchora arbuscula, Svenzea tubulosa, Neopetrosia proxima, Neopetrosia subtriangularis, Neopetrosia carbonaria, Xestospongia muta, Neopetrosia rosariensis, Petrosia pellasarca, Ptilocaulis wallpersi, Topsentia ophiraphidites, Lissodendoryx colombiensis, Amphimendon caycedoy and the zoanthid Palythoa caribbaeorum. Identification of the species was done by Dr. Sven Zea and Dr. Mónica Puyana. Vouchers of each one of the studied species are at the Instituto de Ciencias Naturales, Universidad Nacional de Colombia, Bogotá, Colombia and at the Instituto de Investigaciones Marinas y Costeras "José Benito Vives De Andréis" Invemar, Santa Marta, Colombia Collections. Once the organisms had been collected and rinsed with sterile sea water to remove associated debris, they were frozen until extraction. Then the samples were cut into small pieces and extracted by maceration in $\mathrm{CH}_{2} \mathrm{Cl}_{2} / \mathrm{MeOH}$ (1:1) for $24 \mathrm{~h}$, three times. The extract, obtained after filtration, was then concentrated to dryness under vacuum at $40{ }^{\circ} \mathrm{C}$, and stored at $4{ }^{\circ} \mathrm{C}$ until use.

The algae were collected at Santa Catarina coast, by means of scuba diving, in September 2005, March 2006, and February 2008. The samples included the five Laurencia species: $L$. catarinensis, L. microcladia, L. majuscula, L. flagelifera, and L. obtusa, and one Peyssonelia species: P. capensis. Identification of the species was done by Prof. Paulo Antunes Horta Junior, Department of Botany, Federal University of Santa Catarina, Florianopolis, Brazil. Vouchers of each one of the studied species have been deposited at the herbarium of this department. After collection and rinsing with sterile sea water to remove associated debris, the algae were air-dried. Then the samples were cut into small pieces and extracted by maceration in $\mathrm{MeOH}$, $\mathrm{CH}_{2} \mathrm{Cl}_{2} / \mathrm{MeOH}$ (1:1), and $\mathrm{CH}_{2} \mathrm{Cl}_{2}$ for $48 \mathrm{~h}$ each. The extract, obtained after filtration, was concentrated to dryness under vacuum at $40{ }^{\circ} \mathrm{C}$, and stored at $4{ }^{\circ} \mathrm{C}$ until use.

Antibacterial activities

The test of the extracts against the Caribbean marine bacteria isolates was performed using a standard agar disc diffusion assay (Hewitt and Vincent, 1989). Bacterial strains were incubated between 18 and $24 \mathrm{~h}$ in artificial marine broth (Smith and Hayasaka, 1982; Mora-Cristancho et al., 2008) at $(25 \pm 3){ }^{\circ} \mathrm{C}$. Bacteria concentration was adjusted to $10^{8} \mathrm{CFU} \mathrm{mL} \mathrm{m}^{-1}$ with $0.5 \mathrm{McFarland}$ standard before spreading the bacterial suspension onto GASW agar. Whatman GF-C filter paper discs $(5.2 \mathrm{~mm}$ i.d.) were loaded with $300 \mu \mathrm{g}$ of extract and then placed in the agar with the bacteria. After incubation for $48 \mathrm{~h}$ at $(25 \pm 2){ }^{\circ} \mathrm{C}$, the diameter of the inhibition zones around the discs was measured. Control tests with the solvents $\mathrm{CH}_{2} \mathrm{Cl}_{2}, \mathrm{MeOH}$, and DMSO were carried out in each plate showing no inhibition of bacterial growth. In addition, positive control discs with $30 \mu \mathrm{g}$ of the biocide $\mathrm{Cu}_{2} \mathrm{O}\left(10 \mu \mathrm{g} \mathrm{mL}^{-1}\right.$ in water $)$ were used. All inhibition assays were carried out in triplicate. The data presented here corresponds to the average of the diameter of inhibition zone. 


\section{Results and Discussion}

Molecular characterization of marine bacteria used for standard bioassays

Twelve bacterial isolates from surfaces of the sponges Aplysina insularis and Aplysina lacunosa, from the shell of the bivalve Donax sp., and from Phytagel $^{\mathrm{TM}}$ Petri plates immersed for $48 \mathrm{~h}$ in sea water were isolated, characterized by biochemical tests, macro- and microscopically, and identified by $16 \mathrm{~S}$ rRNA gene sequences analyses (Table I).

All characterized isolates were Gram-negative except 1,4 , and 9 . They grew aerobically at room temperature. Standard biochemical tests were performed for preliminary identification [citrate, lysine decarboxylase, sulfide-indol-motility (SIM), and methyl red (MR), data not shown].

The 16S rRNA genes of the marine bacterial isolates were sequenced and the sequences subsequently aligned to currently available $16 \mathrm{~S}$ rRNA gene sequences; they showed significant similarity to sequences from the GenBank and the $\mathrm{Eu}-$ ropean Molecular Biology Laboratory (EMBL) nucleotide sequence databases. For comparison we selected the most similar sequences from recognized type strain collections such as ATCC (American Type Culture Collection). A derived multiple sequence alignment was used to generate a pairwise similarity matrix and genetic distances between our strains and related bacteria. Some of the sequences could be assigned to a bacterial species but others were sufficiently similar to the type strains (Table I).

The tree topology shown in Fig. 1 was obtained using the neighbour-joining method (Saitou and Nei, 1987), and distances were calculated with the Kimura two-parameter method computing the units of the number of base substitutions per site (Kimura, 1980). Statistical evaluation of genetic divergences was performed by bootstrap resampling of the sequence data.

Since Vacelet (1975), studies on sponge-associated microorganisms have focused on communities inhabiting the mesohyl and the interior of the sponge cells. Significant progress has been made in these studies. However, the knowledge about epibiotic bacteria and their role in the ecology of marine sponges is still unexplored. This study is one of the few in which bacteria have been isolated from sponge surfaces, and some of these bacteria correspond consistently to some of those reported in other studies on Aplysina spp. tis- sue matrix (Friedrich et al., 1999). Even though we found differences (probably due to the fact that we sampled the epibiotic community from the sponges) in general we can mention coincidences in case of some Gram-positive bacteria (Bacillus), $\gamma$-proteobacteria (Vibrio, Pseudoalteromonas), and $\alpha$-proteobacteria (Ochrobactrum) (Friedrich et al., 1999; Ahn et al., 2003). Others of our isolates are similar to Pseudoalteromonas, Vibrio, and Bacillus, that are widespread bacteria in marine environments associated with sponges, tunicates, mussels, pufferfish, and algae (Rao et al., 2005; Allers, 2007).

Strains $1,3,7,9$, and 11 had a satisfactory classification with identity percentages higher than 97\%. Strain 1 has $98 \%$ similarity with Oceanobacillus iheyensis strain HTE831, which was isolated from deep sea mud and is extremely halophilic and alkaliphilic. These characteristics are common also for our isolate (Liu et al., 2001). However, we found this bacterium in relatively shallow depth and as biofilms on calcareous surfaces. Strain 3 has 99\% similarity with Ochrobactrum pseudogrignonense. It is interesting to note that such species has been isolated mostly in the East China Sea, and there are no reports on this species in the Caribbean Sea. It has been related with $N$ acyl-homoserine lactone degradation that could be a clue to its role on the surfaces of non-fouled organisms (Zhou et al., 2008). Strain 7 has 97\% sequence similarity with Vibrio campbellii which has been isolated several times from sea water. $V$. campbellii occurs in the open ocean at high frequency, and it has been proposed that it represents an autochthonous species in surface waters of the Atlantic Ocean (Grimes et al., 1986). Strain 9 is the only one showing $100 \%$ similarity with a known species, i.e. Bacillus megaterium. Strain 11 has $98 \%$ similarity with Vibrio harveyi. This bacterium is common in the oceans of the world; it can be found easily in non-extreme environments and subtropical waters. It is thought that Vibrio are the most abundant cultivatable bacteria in marine environments. It has been reported that the genera Vibrio-Photobacterium usually represent up to $2 \cdot 10^{8}$ cells $\mathrm{L}^{-1}$ out of the $2.6 \cdot 10^{10}$ bacteria (Heidelberg et al., 2002). They are present in normal microbiota of common marine organisms and are associated with both diseased and healthy aquatic animals (Thompson et al., 2003).

The isolates identified in this study as Ochrobactrum pseudogrignonense, Vibrio campbellii, 
J. A. Mora-Cristancho et al. · Antifouling Activity of Marine Invertebrates

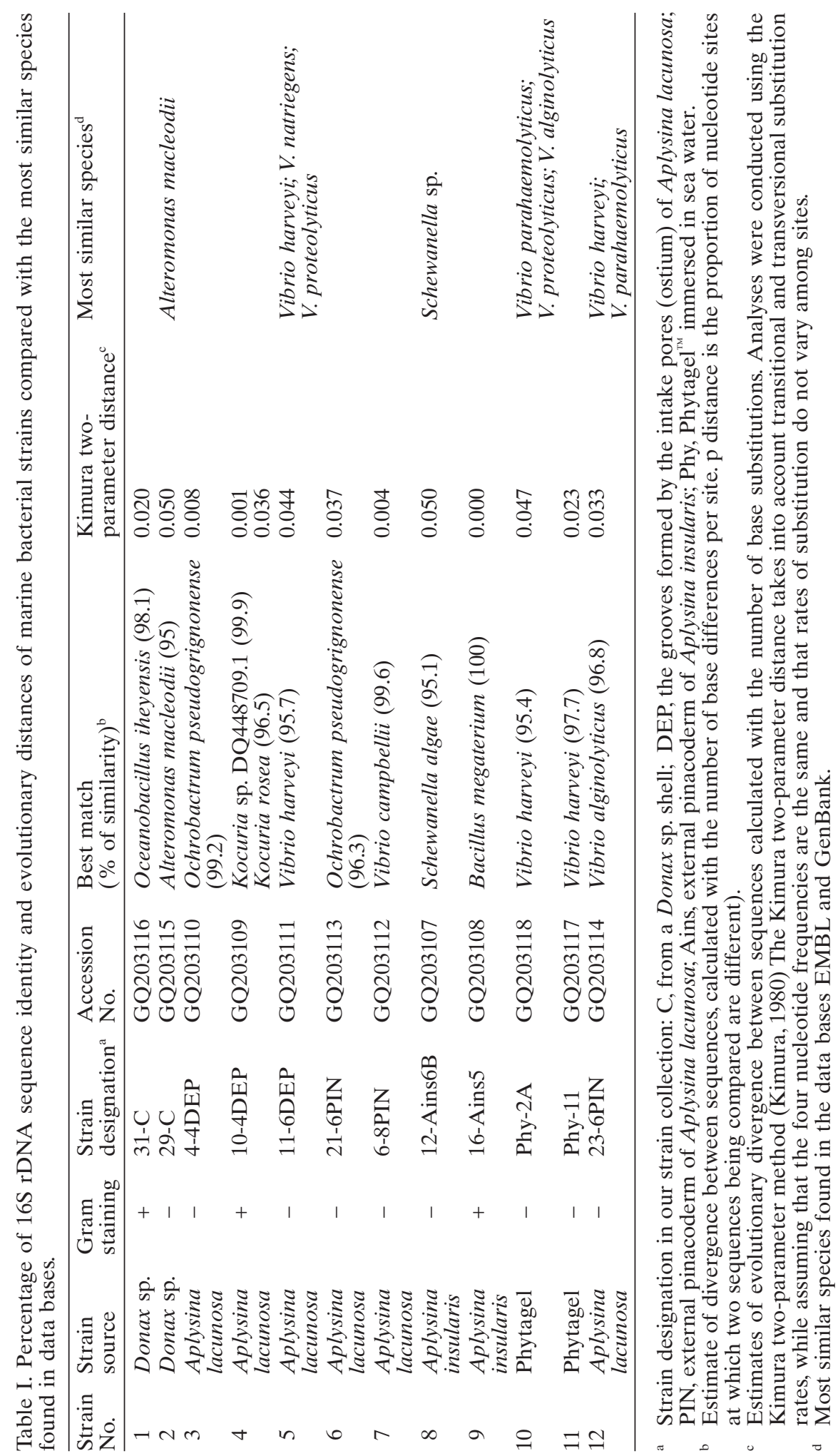




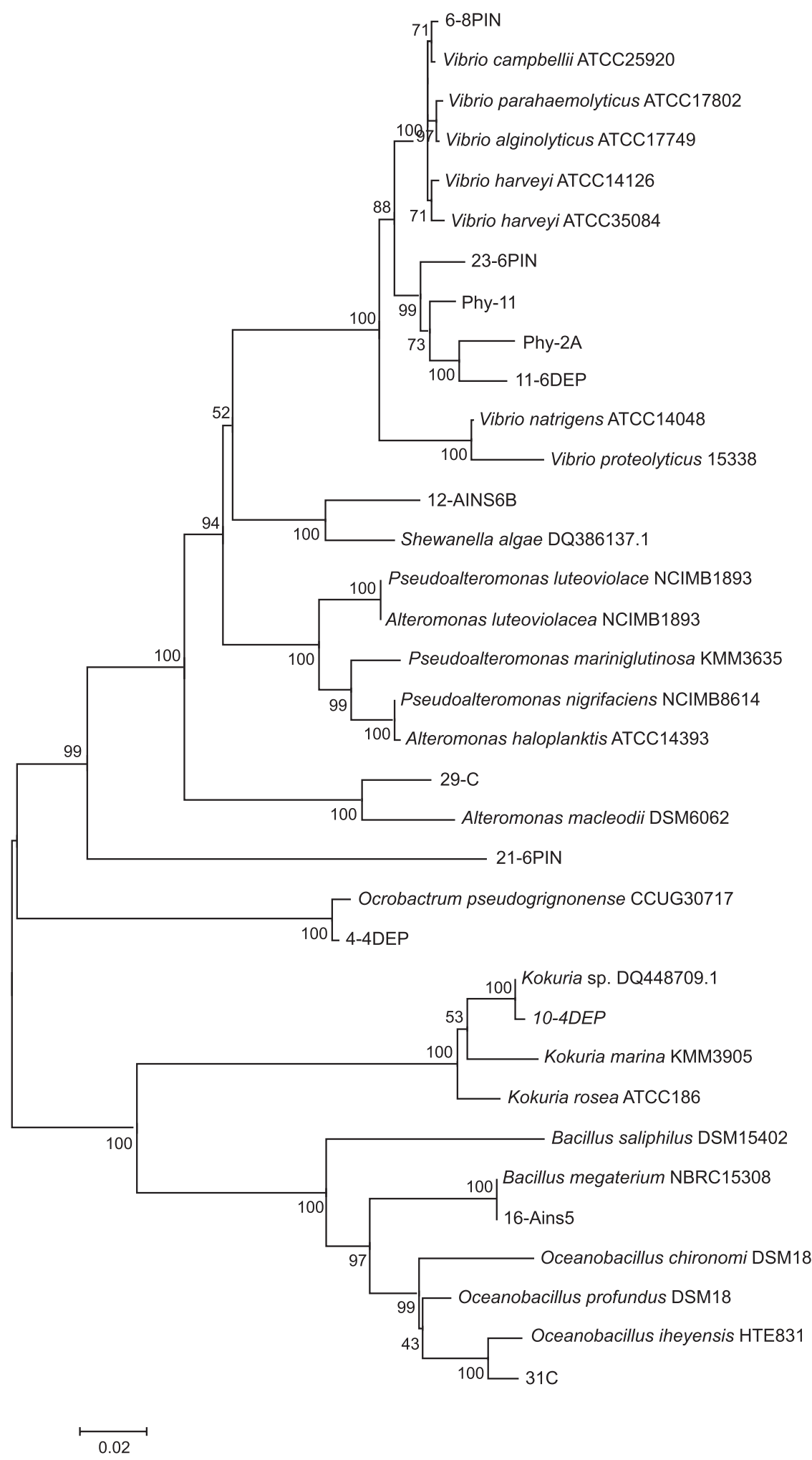


Fig. 1. Tree of marine bacterial isolates based on 16S rDNA gene sequence. The dendogram was inferred using the neighbour-joining method. The optimal tree with the percentage of replicate trees, in which the associated taxa are clustered, and the bootstrap test (1000 replicates) are shown next to the branches. The evolutionary distances were computed using the Kimura two-parameter method (Kimura, 1980) and are in the units of the number of base substitutions per site. Phylogenetic analyses were conducted in MEGA4. Collections: ATCC, American Type Culture Collection; NCIMB, National Collection of Industrial, Marine and Food Bacteria; KMM, Collection of Marine Microorganisms of the Pacific Institute of Bioorganic Chemistry of the Far-Eastern Branch of the Russian Academy of Sciences; DSMZ, Deutsche Sammlung von Mikroorganismen und Zellkulturen (DSM in figure); CCUG, Culture Collection of the University of Göteborg; NBRC, NITE Biological Resource Center, Japan; HTE831 is the type strain of the Japan Agency for Marine-Earth Science and Technology [Japan MSTC (JAMSTEC)]. PIN, Phy, Ains, $\mathrm{C}$, and DEP refer to the designation in our strain collection (Table I).

and Bacillus megaterium have not been reported before for Aplysina sponges. Isolate 4 is related to high G+C Gram-positive bacteria (Kocuria) having $96.5 \%$ sequence similarity with Kocuria rosea and even $99.9 \%$ with another Kocuria strain that has not yet been properly classified (Kocuria sp. DQ448709.1) (Gontang et al., 2007). It may be interesting to explore if our isolate and the referenced one could belong to a species taxonomically separated from that genus.

For strain 2, further comparison is required to find out to which species of the genus Alteromonas it is most similar, given that the present members of this taxon are related by $16 \mathrm{~S}$ rDNA sequence identities below $95 \%$. The same is true for strains $5,6,8,10$, and 12 which are between 95 and $97 \%$ similar to the most comparable species found in the data bases (Rosello-Mora and Amann, 2001).

\section{Antibacterial activity of extracts of marine invertebrates}

The antibacterial activity of extracts of 33 marine invertebrates (soft corals, sponges, and a zoanthid) collected in the Colombian Caribbean Sea and of 6 marine algae collected on the Brazilian coast against 12 potentially fouling marine bacterial strains is shown in Table II. Among different copper compounds commonly used as antifoulants (Yebra et al., 2004), copper(I) oxide was chosen as the positive control in the antimicrobial assay due to its activity profile against the strains selected here. Other well known antifouling copper salts, such as $\mathrm{CuSO}_{4}$ and $\mathrm{CuCl}_{2}$, were also tested in a wide range of concentrations, but the bacterial strains were remarkably resistant to these salts (data not shown).

Seven out of the 39 extracts of marine organisms had high activity against the tested bacterial strains, 10 extracts presented mild activity, 14 extracts showed low activity, and the other 8 extracts had negligible activity (Table II). Among the soft corals, the extracts of Pseudopterogorgia elisabethae (chemotype 1 and chemotype 2), Eunicea knighti, Eunicea fusca, Eunicea succinea, Eunicea laciniata, and Eunicea sp. 2 showed high to mild activity, respectively, and Eunicea tayrona and Muriceopsis sp. had low or no activity. The extracts of the sponges, Topsentia ophiraphidites, Agelas citrina, Neopetrosia carbonaria, and Monanchora arbuscula strongly inhibited bacterial growth, Cliona tenuis, Ptilocaulis wallpersi, Iotrochota imminuta, Svenzea tubulosa, Oceanapia peltata, and Neopetrosia muta were mildly inhibitory, while Neopetrosia proxima, Neopetrosia rosariensis, Lissodendoryx colombiensis, Agelas conifera, Dragmacidon reticulata, and Biemna cribaria weakly inhibited bacterial growth. The other six sponges had no remarkable activity. The extracts of algae showed low inhibition of bacterial growth. Laurencia obtusa was mildly active against 3 out of the 12 bacterial strains used. The extract of Palythoa caribbaeorum was mildly active against 4 out of the 12 bacterial strains used.

Extracts of Pseudopterogorgia elisabethae produced the largest inhibition zones and inhibited the widest range of strains; they have not been studied previously for their antibacterial or antifouling activity against bacteria isolated from a community associated to the surface of marine organisms. However, Pseudopterogorgia elisabethae has been widely investigated for the presence of diterpenes, mainly pseudopterosins, and related compounds that have proven activity as anti-inflammatory compounds (Correa et al., 2009). In Colombia, two chemotypes with different and characteristic contents of pseudopterosins and secopseudopterosins have been reported as the result of our research and several new compounds have been isolated (Duque et al., 2006). The antibacterial activity profiles of both chemotypes were very similar in the number of strains as well as in the strength of the activity, probably 
Table II. Antifouling activity of extracts of marine invertebrates.

\begin{tabular}{|c|c|c|c|c|c|c|c|c|c|c|c|c|}
\hline \multirow[t]{2}{*}{ Sample } & \multicolumn{12}{|c|}{ Growth inhibition of colonizer marine bacterial strains } \\
\hline & 1 & 2 & 3 & 4 & 5 & 6 & 7 & 8 & 9 & 10 & 11 & 12 \\
\hline \multicolumn{13}{|l|}{ Soft corals } \\
\hline $\begin{array}{l}\text { Pseudopterogorgia elisabethae } \\
\text { (SA) }\end{array}$ & +++ & - & - & ++ & N.E. & - & ++++ & - & +++ & ++++ & - & ++++ \\
\hline $\begin{array}{l}\text { Pseudopterogorgia elisabethae } \\
\text { (P) }\end{array}$ & +++ & - & - & ++++ & N.E. & - & ++++ & - & ++++ & - & ++++ & ++++ \\
\hline Eunicea knighti & + & - & ++ & + & ++ & - & ++ & ++++ & - & - & + & ++++ \\
\hline Eunicea succinea & + & - & + & - & + & - & - & - & +++ & +++ & - & - \\
\hline Eunicea fusca & ++++ & - & + & - & - & - & ++++ & ++++ & ++ & - & ++ & +++ \\
\hline Eunicea sp. 2 & ++ & - & - & - & - & - & - & - & ++ & - & - & - \\
\hline Eunicea tayrona & + & N.E. & + & - & + & + & N.E. & N.E. & N.E. & N.E. & N.E. & N.E. \\
\hline Eunicea laciniata & ++ & - & ++ & - & + & - & ++ & +++ & + & ++ & + & ++ \\
\hline Erythropodium caribaeorum & - & - & - & - & + & - & - & - & - & +++ & - & ++++ \\
\hline Muriceopsis sp. & - & - & - & - & - & - & - & - & - & - & - & - \\
\hline \multicolumn{13}{|l|}{ Sponges } \\
\hline Biemna cribaria & - & - & - & - & ++ & - & - & - & - & - & - & - \\
\hline Iotrochota imminuta & + & - & ++ & ++ & ++ & - & - & - & + & ++++ & - & - \\
\hline Dragmacidon reticulata & - & - & - & - & + & - & - & - & ++ & - & - & - \\
\hline Oceanapia peltata & - & - & - & - & +++ & - & - & - & - & - & - & ++++ \\
\hline Cinachyrella kuekenthali & - & - & - & - & + & - & - & - & - & - & - & - \\
\hline Spirastrella coccínea & - & - & - & - & - & - & - & - & - & - & - & - \\
\hline Cliona tenuis & - & - & - & - & - & - & +++ & - & - & - & - & +++ \\
\hline Cliona delitrix & - & - & + & - & - & - & - & - & - & - & - & - \\
\hline Agelas conifera & + & - & - & ++ & - & - & - & - & ++ & - & - & - \\
\hline Agelas citrina & ++++ & - & - & ++++ & ++++ & - & - & - & + & + & ++ & +++ \\
\hline Monanchora arbuscula & ++++ & - & + & ++++ & - & - & + & - & ++ & + & - & - \\
\hline Svenzea tubulosa & ++++ & - & - & - & - & - & - & - & ++++ & - & - & - \\
\hline Neopetrosia proxima & - & - & - & - & - & - & - & - & - & +++ & - & - \\
\hline Neopetrosia subtriangularis & - & - & - & - & - & - & - & - & - & - & - & - \\
\hline Neopetrosia carbonaria & ++++ & - & - & ++++ & ++ & - & - & - & ++++ & - & - & - \\
\hline Neopetrosia rosariensis & - & - & - & - & - & ++++ & - & - & - & - & - & - \\
\hline Xestospongia muta & - & - & - & - & - & - & - & - & + & +++ & - & - \\
\hline Petrosia pellasarca & - & - & - & - & - & - & - & - & - & - & - & - \\
\hline Ptilocaulis wallpersi & ++++ & - & - & +++ & - & - & - & - & ++ & - & - & - \\
\hline Topsentia ophiraphidites & ++++ & + & - & ++++ & ++++ & ++++ & ++++ & - & ++++ & + & ++++ & ++++ \\
\hline Lissodendoryx colombiensis & - & - & - & - & - & ++ & + & - & - & ++ & ++ & - \\
\hline Amphimendon caycedoy & - & - & - & - & - & - & - & - & - & - & - & - \\
\hline \multicolumn{13}{|l|}{ Zoanthid } \\
\hline Palythoa caribbaeorum & ++ & - & - & - & ++ & - & ++ & - & - & - & - & ++ \\
\hline \multicolumn{13}{|l|}{ Algae } \\
\hline Laurencia catarinensis & - & - & + & - & - & - & - & - & - & - & - & - \\
\hline Laurencia microcladia & - & - & + & - & - & - & - & - & - & - & - & - \\
\hline Laurencia majuscula & - & - & + & - & - & - & - & - & - & - & - & - \\
\hline Laurencia flagelifera & - & - & - & - & - & - & - & - & - & - & - & - \\
\hline Laurencia obtusa & + & - & ++++ & - & - & - & + & - & - & - & - & - \\
\hline Peyssonelia capensis & - & - & - & - & - & + & + & - & - & - & - & - \\
\hline $\mathrm{Cu}_{2} \mathrm{O}$ & ++ & ++++ & +++ & - & ++ & ++ & ++++ & ++ & + & ++++ & ++ & ++++ \\
\hline
\end{tabular}

The inhibitory activity is expressed as the diameter (in $\mathrm{mm}$ ) of the inhibition zone $48 \mathrm{~h}$ after the test. -, no inhibition; +, 6.2-8.1; ++, 8.2-10.1; +++, 10.2-12.1; ++++, >12.1; N.E, not evaluated. Disc diameter, 5.2 mm. Concentration of extracts, $300 \mu \mathrm{g}$ disc ${ }^{-1}$. Positive control, $30 \mu \mathrm{g}$ disc $^{-1} \mathrm{Cu}_{2} \mathrm{O}$. Discs with the mixture of solvent extraction were used in each Petri dish as a control. 
due to the presence of pseudopterosin-type compounds in both chemotypes.

The extracts of the Eunicea species, one of the most common genera of soft corals present in the Caribbean Sea, showed strong inhibition of bacterial growth. Eunicea knighti, Eunicea fusca, and Eunicea laciniata have the most interesting activity profiles according to the number of strains inhibited as well as the strength of the inhibitory effect. Studies on these soft corals identified them as a rich source of cembranoid and fuscoside diterpenes, and some sesquiterpenes (Rodriguez, 1995). Several biological activities, such as antimicrobial, cytotoxic, and acetylcholine inhibitory activities, were reported for compounds isolated from soft corals belonging to this genus (Berrue and Kerr, 2009). Several cembranolides exhibiting cytotoxic and antibacterial activity have been isolated from Eunicea succinea (Rodriguez, 1995). Eunicea fusca contains fuscosides A-D, i.e. glycosydically bound diterpenes with skeletons related to lobane and eudesmane, which have an interesting anti-inflammatory activity (Jacobson and Jacobs, 1992).

The extract of Topsentia ophiraphtidites, the most active one of all of our antifouling samples reported here, is a rich source of oxylipins, steroids including steroid sulfates, and nitrogen-containing steroids (Luo et al., 2006; Alvi et al., 1991). Although no studies have been done on the antibacterial activity of these compounds, they have proven antihelmintic and cytotoxic activities. Several $3-\beta-\Delta^{5}$-steroids were identified by us in previous chemical studies in specimens collected at the Colombian Caribbean Cost (Echigo et al., 2006).

The extract of the marine sponge Agelas citri$n a$ had some of the stronger inhibitory activities among the invertebrates tested here. Inhibition of four out of the 12 strains evaluated, as well as a mild inhibition of three other strains can be observed (Table II). On the other hand, Agelas conifera exhibited a low growth inhibitory effect on three strains. The Caribbean Agelas sponges are one of the most studied genera with a wide variety of metabolites of mixed metabolic origin (i.e. terpenoids, pyrrol and 2-aminoimidazole alkaloids, and halogenated compounds) and with a wide range of reported biological activities. Bromoageliferin and other 2-aminoimidazole derivatives inhibit biofilm formation by two planktonic bacterial strains of Pseudomonas aeruginosa (Huigens et al., 2007). Agelasine D and its synthetic analogues were shown to have antifouling activity against the barnacle Balanus improvisus (Sjögren et al., 2008). Previous studies on Agelas conifera, a rich source of pyrrolidine alkaloids, revealed an inhibitory effect of these compounds on the settlement of Vibrio harveyi (Kelly et al., 2003). As far as we know, Agelas citrina has not been subjected to chemical studies.

The antibacterial activity of four extracts of sponges of the genus Neopetrosia (previously classified as Xestospongia) and Xestospongia muta are presented in Table II. The strongest bacterial growth inhibitory effect was observed for Neopetrosia carbonaria, followed by Neopetrosia rosariensis, Xestospongia muta, Neopetrosia proxima, and Neopetrosia subtringularis, respectively. Several species of Neopetrosia collected in the Pacific Ocean, many of them unclassified, have been chemically explored in the search for bioactive compounds. From the studied species, original steroids (aragusterols), acetylenes, tetrahydrofurans, quinones and hydroquinones (xestoquinones), as well as a wide variety of alkaloidal compounds such as xestospongins, araguspongins, motuporamines, aaptamines, and renieramycins have been isolated (Laurent et al., 2006; Cao et al., 2005). Neopetrosia carbonaria, which also exhibited strong inhibitory activity among the sponges tested, contains the purple pyridoacridines and pyrroloacridines with strong cytotoxic activity (Thale et al., 2002). Neopetrosia proxima and Xestospongia muta showed low inhibition of the marine bacteria tested here. From Xestospongia muta, the Caribbean barrel sponge, some acetylenic tetrahydrofuran compounds were isolated (Morinaka et al., 2007). Extracts of Neopetrosia proxima collected in the Colombian Caribbean strongly inhibited human pathogenic strains of Staphylococcus aureus, Streptococcus faecalis, Pseudomonas aeruginosa, and Escherichia coli (Mora-Cristancho et al., 2008). To our knowledge, no activity studies against marine colonizer bacteria or against other fouling organisms have been conducted with sponges of this genus.

The Monanchora arbuscula extract with strong antibacterial activity selective to strains 1 and 4 in the present study, contains mainly polycyclic guanidinic alkaloids with antibacterial, antifungal, antiviral and cytotoxic activities against tumour cell lines (Chang et al., 2003). Iotrochota imminuta has not been the subject of chemical or antifouling studies, however, its potential as an antibacte- 
rial agent has been evaluated (Mora-Cristancho et al., 2008). Additionally, some bioactive aromatic alkaloids have been reported from other species of the same genera (Chan et al., 1993).

Red algae of the genus Laurencia are cosmopolitan species with a wide distribution throughout the world. Species of this genus (order Ceramiales, family Rhodomelaceae) were proven to be a prolific source of structurally unusual and biologically active halogenated metabolites. We obtained similar results (Table II) for the extracts of Laurencia catarinensis, Laurencia microcladia, and Laurencia majuscule, and these are possible related to the common presence of elatol, characterized by chromatographic analyses of extracts of all these species (Lhullier et al., 2010). The most potent antibacterial activity of the tested algal extracts was observed for Laurencia obtusa. The presence of elatol was reported for Laurencia obtusa collected in the Rio de Janeiro State of Brazil (Salgado et al., 2008). For elatol, a potent antibacterial activity was previously reported against some marine bacteria and also against human pathogenic bacteria (Vairappan et al., 2003). More complete investigations of the antifouling properties have been performed with Laurencia rigida extract, and the observed activity was attributed to the presence of elatol (König and Wright, 1997). On the other hand, in the tested Laurencia flagelifera extract, neither the presence of elatol or other related halogenated sesquiterpenes nor antibacterial activity were observed. A different activity profile was observed for the extract of Peyssonelia capensis; for this species there exists no previous report concerning antibacterial activity. Chemical investigation of Peyssonelia species collected in the Red Sea revealed the accumulation of two sesquiterpene hydroquinones, called peyssonol $\mathrm{A}$ and $\mathrm{B}$, and these two compounds showed antiviral activity against HIV-1 and HIV-2 (Loya et al., 1995).

The bacteria selected for the present study covered both, strains sensible and resistant to the extracts. The Gram-positive Oceanobacillus iheyensis (1), Kocuria sp. DQ448709.1 (4), and Bacillus megaterium (9) were sensitive, while the Gram-negative strains were either sensitive or resistant. The strain of Alteromonas macleodii (2) was strongly resistant against the tested extracts, and Ochrobactrum pseudogrignonense (6) was only susceptible to Neopetrosia carbonaria and Topsentia ophiraphidites extracts. On the other hand, more sensible strains, such as Vibrio campbellii (7) and strain 12, were susceptible to a wide range of extracts which produced high to moderate growth inhibition zones. Some of the more interesting strains are 10 and 11 , which were obtained from a gel immersed for $48 \mathrm{~h}$, and thus possibly represent first colonizers on a surface. Strain 10 was inhibited by some of the active extracts of corals and sponges, while strain 11 was inhibited only by some of the octocoral extracts and by the Topsentia ophiraphidites and Lyssodendoryx colombiensis sponges extracts. No correlation between the source of a strain and inhibition can be derived from these data. However, it is clear that soft coral extracts are more inhibitory to the bacterial strains than sponges extracts.

In conclusion, fouling can be understood as a successive process that involves bacterial settlement and biofilm formation as the first steps. The settlement of macroorganisms is mediated by chemical cues originating mainly from the biofilm (Fusetani, 2004). Thus, inhibition of bacterial strains in colonized surfaces opens the perspective to find substances able to inhibit or delay the fouling process in its early stages. The results on the antibacterial activities presented here suggest the importance of carrying out studies on the chemical composition and antifouling activities of the soft corals Pseudopterogorgia elisabethae, Eunicea knighti, Eunicea fusca, Eunicea laciniata, and Eunicea succinea, and of the sponges Topsentia ophiraphidites, Agelas citrina, Neopetrosia carbonaria, Monanchora arbuscula, Cliona tenuis, Iotrochota imminuta, and Ptilocaulis walpersii. We have previously isolated several cembradiene diterpenoids (Tello et al., 2009), a glycosylated pregnane, and dolabellanes from some of these species and a mixture of three known sterols from E. succinea (Cuadrado et al., 2010) as compounds with antifouling activity against the bacteria tested here. Such studies are presently conducted in our group for Eunicea fusca and Pseudopterogorgia elisabethae.

\section{Acknowledgement}

This work was conducted as part of a bilateral (Brazil and Colombia) cooperative project financially supported by CNPq/MCT/Brazil (grant number 490151/2007-8) and COLCIENCIAS/ Colombia (grant number 358-2007). Part of the work was also financed by COLCIENCIAS 
(grant number 20101007015), by Fundación para la Promoción de la Investigación y la Tecnología del Banco de la República (grant number 200603 and 2057), and by DIB of the Universidad Nacional de Colombia (grant number 20101007467). The Ministerio de Ambiente, Vivienda y Desarrollo Territorial granted permission (permission No. 4 of 10/02/2010, addendum resolución 0306 of 22/02/2011) for collecting samples and per-

Ahn Y. B., Rhee S. K., Fennell D. E., Kerkhof L. J., Hentschel U., and Häggblom M. M. (2003), Reductive dehalogenation of brominated phenolic compounds by microorganisms associated with the marine sponge Aplysina aerophoba. Appl. Environ. Microbiol. 69, 4159-4166.

Allers E. (2007), Response of Marine Bacterioplankton to Experimental Manipulations of Growth Conditions. Dissertation. Faculty of Biology/Chemistry, University of Bremen, Bremen, p. 135.

Alvi K. A., Tenenbaum L., and Crews P. (1991), Antihelmintic polyfunctional nitrogen-containing terpenoids from marine sponges. J. Nat. Prod. 54, 71-78.

Berrue F. and Kerr R. G. (2009), Diterpenes from gorgonian corals. Nat. Prod. Rep. 26, 681-710.

Briand J. F. (2009), Marine antifouling laboratory bioassays: an overview of their diversity. Biofouling 25, 297-311.

Cao S., Foster C., Brisson M., Lazo J. S., and Kingston D. G. I. (2005), Halenaquinone and xestoquinone derivatives, inhibitors of Cdc25B phosphatase from a Xestospongia sp. Bioorg. Med. Chem. 13, 999-1003.

Chan G. W., Francis T., Thureen D. R., Offen P. H., Pierce J. W., Westley J. W., Johnson R. K., and Faulkner D. J. (1993), Purpurone, an inhibitor of ATP-citrate lyase: a novel alkaloid from the marine sponge Iotrochota sp. J. Org. Chem. 58, 2544-2546.

Chang L. C., Whittaker N. F., and Bewely C. (2003), Crambescidin 826 and dehydrocrambine A: new polycyclic guanidine alkaloids from the marine sponge Monanchora sp. that inhibit HIV-1 fusion J. Nat. Prod. 66, 1490-1494.

Correa H., Valenzuela A. L., Ospina L. F., and Duque C. (2009), Antiinflammatory effects of the gorgonian Pseudopterogorgia elisabethae collected at the islands of Providencia and San Andres (SW Caribbean). J. Inflammation 6, 5 .

Cuadrado C. T., Castellanos L., Osorno O., Ramos F. A., Duque C., and Puyana M. (2010), Chemical study and antifouling activity of caribbean octocoral Eunicea laciniata. Quim. Nova 33, 656-661.

Dobretsov S. and Qian P. Y. (2004), The role of the epibiotic bacteria from the surface of the soft coral Dendronephthya sp. in the inhibition of larval settelement. J. Exp. Mar. Biol. Ecol. 299, 35-50.

Duque C., Puyana M., Castellanos L., Arias A., Correa H., Osorno O., Asai T., Hara N., and Fujimoto Y. (2006), Further studies on the constituents of the gorgonian forming research on marine organisms collected at Santa Marta Bay and at the Rosario Islands, Colombian Caribbean. The Colombian authors greatly acknowledge Prof. Dr. Ute Hentschel from the University of Würzburg, Germany, Prof. Dr. Sven Zea from the Universidad Nacional de Colombia, and Dr. Diego L. Gil from INVEMAR (Santa Marta, Colombia) for their interest and assistance in this work.

coral Pseudopterogorgia elisabethae collected in San Andres and Providencia islands, Colombian Caribbean: Isolation of a putative intermediate leading to erogorgiaene. Tetrahedron 62, 4205-4213.

Echigo S., Hara N., Calderón G. J., Duque C., and Fujimoto Y. (2006), C-24 stereochemistry of marine sterols: (22E)-24-(Isopropenyl)-22-dehydrocholesterol and 24-isopropenylcholesterol. Chem. Pharm. Bull. 54, $1473-1477$.

Friedrich A. B., Merkert H., Fendert T., Hacker J., Proksch P., and Hentschel U. (1999), Microbial diversity in the marine sponge Aplysina cavernicola (formely Verongia cavernicola) analyzed by fluorescence in situ hybridization (FISH). Mar. Biol. 34, 461-470.

Fusetani N. (2004), Biofouling and antifouling. Nat. Prod. Rep. 21, 94-104.

Fusetani N. (2011), Antifouling marine natural products. Nat. Prod. Rep. 28, 400-410.

Fusetani N. and Clare A. (2006), Marine molecular biotechnology. In: Antifouling Compounds (Fusetani N. and Clare A. S., eds.). Springer, Berlin, Heidelberg, p. VI.

Gontang E. A., Fenical W., and Jensen P. R. (2007), Phylogenetic diversity of Gram-positive bacteria cultured from marine sediments. Appl. Environ. Microbiol. 73, 3272-3282.

Grimes D. J., Brayton P. R., West P. A., Singleton F. L., and Colwell R. R. (1986), The probabilistic identification of Vibrio spp. isolated from surface seawater with special reference to Vibrio campbellii. Lett. Appl. Microbiol. 2, 93-95.

Heidelberg J. F., Heidelberg K. B., and Colwell R. R. (2002), Seasonality of Chesapeake Bay bacterioplankton species. Appl. Environ. Microbiol. 68, 5488-5497.

Henrikson A. A. and Pawlik J. R. (1995), A new antifouling assay method: results from field experiments using extracts of four marine organisms. J. Exp. Mar. Biol. Ecol. 194, 157-165.

Hewitt W. and Vincent S. (1989), The agar diffusion assay. In: Theory and Application of Microbiological Assay (Hewitt W. and Vincent S., eds.). Academic Press Inc., San Diego, pp. 38-79.

Huang X. and Madan A. (1999), CAP3: A DNA sequence assembly program. Genome Res. 9, 868-877.

Huigens R. W., Richards J. J., Parise G., Ballard T. E., Zeng W., Deora R., and Melander C. (2007), Inhibition of Pseudomonas aeruginosa biofilm formation 
with bromoageliferin analogues. J. Am. Chem. Soc. 129, 6966-6967.

Jacobson P. B. and Jacobs R. S. (1992), Fuscoside: An antiinflammatory marine natural product which selectively inhibits 5-lipoxygenase. Part I: Physiological and biochemical studies in murine inflammatory models 1 . J. Pharmacol. Exp. Ther. 262, 866-863.

Kelly S. R., Jensen P. R., Henkel T. P., Fenical W., and Pawlik J. R. (2003), Effects of Caribbean sponge extracts on bacterial attachment. Aquat. Microbiol. Ecol. 31, $175-182$.

Kimura M. (1980), A simple method for estimating evolutionary rate of base substitutions through comparative studies of nucleotide sequences. J. Mol. Evol. 16, $111-120$

König G. M. and Wright A. D. (1997), Laurencia rigida: chemical investigations of its antifouling dichloromethane extract. J. Nat. Prod. 60, 967-970.

Krug P. J. (2006), Defense of benthic invertebrates against surface colonization by larvae: A chemical arms race. In: Antifouling Compounds (Fusetani N. and Claire A., eds.). Springer, Berlin, Heidelberg, pp. 1-41.

Lane D. J. (1991), 16S/23S rRNA sequencing in nucleic acid techniques. In: Bacterial Systematics (Stackebrandt E. and Goodfellow M., eds.). Wiley, New York, pp. $115-175$.

Larkin M. A., Blackshields G., Brown N. P., Chenna R., McGettigan P. A., and McWilliam H. (2007), Clustal $\mathrm{W}$ and Clustal $\mathrm{X}$ version 2.0. Bioinformatics 23, 2947-2948.

Laurent D., Jullian V., Parenty A., Knibiehler M., Dorin D., Schmitt S., Lozach O., Lebouvier N., Frostin M., Alby F., Maura S., Doerig C., Meijer L., and Savant M. (2006), Antimalarial potential of xestoquinone, a protein kinase inhibitor isolated from a Vanuatu marine sponge Xestospongia sp. Bioorg. Med. Chem. 14, 4477-4482.

Lhullier C., Falkenberg M., Ioannou E., Quesada A., Papazafiri P., Horta P. A., Schenkel E. P., Vagias C., and Roussis V. (2010), Cytotoxic halogenated metabolites from the Brazilian red alga Laurencia catarinensis. J. Nat. Prod. 73, 27-32.

Liu J., Nogi Y., and Takami H. (2001), Oceanobacillus iheyensis gen. nov., sp. nov., a deep-sea extremely halotolerant and alkaliphilic species isolated from a depth of $1050 \mathrm{~m}$ on the Iheya Ridge. FEMS Microbiol. Lett. 205, 291-297.

Loya S., Bakhanashvili M., Kashman Y., and Hizi A. (1995), Peyssonols A and B, two novel inhibitors of the reverse transcriptase of human immunodeficiency virus types 1 and 2. Arch. Biochem. Biophys. 316, 789-796.

Luo X., Li F., Hong J., Lee C. H., Sim C. J., Im K. S., and Jung J. H. (2006), Cytotoxic oxylipins from a marine sponge Topsentia sp. J. Nat. Prod. 69, 567-571.

Mora-Cristancho J. A., Newmark F., Santos-Acevedo U. M., and Sánchez-Nieves J. (2008). Evaluación de extractos de esponjas marinas como nuevas fuentes de sustancias antimicrobianas. Rev. Esp. Quimioter. 21, $174-179$.

Morinaka B. I., Skepper C. K., and Molinski T. F. (2007), Ene-yne tetrahydrofurans from the sponge Xestospongia muta. Exploiting a weak CD effect for assignment of configuration. Org. Lett. 9, 1975-1978.
Qian P. Y., Lau S. C., Dahms H. U., Dobretsov S., and Harder T. (2007), Marine biofilms as mediators of colonization by marine macroorganisms: implications for antifouling and aquaculture. Mar. Biotechnol. 9, $399-410$.

Rao D., Webb J. S., and Kjelleberg S. (2005), Competitive interactions in mixed-species biofilms containing the marine bacterium Pseudoalteromonas tunicata. Appl. Environ. Microbiol. 71, 1729-1736.

Rodriguez A. (1995), The natural products chemistry of West Indian gorgonian octocorals. Tetrahedron 51, 4571-4618.

Rossello-Mora R. and Amann R. (2001), The species concept for prokaryotes. FEMS Microbiol. Rev. 25, 39-67.

Saitou N. and Nei M. (1987), The neighbor-joining method: A new method for reconstructing phylogenetic trees. Mol. Biol. Evol. 4, 406-425.

Salgado L. T., Viana N. B., Andrade L. R., Leal R. N., Da Gama B. A. P., Attias M., Pereira R. C., and Amado G. M. (2008), Intra-cellular storage, transport and exocytosis of halogenated compounds in marine red alga Laurencia obtusa. J. Struct. Biol. 162, 345-355.

Sjögren M., Dahlström M., Hedner E., Jonsson P. R., Vik A., Gundersen L. L., and Bohlin L. (2008), Antifouling activity of the sponge metabolite agelasine D and synthesized analogs on Balanus improvisus. Biofouling 24, $251-258$.

Smith G. W. and Hayasaka S. S. (1982), Nitrogenase activity associated with Halodule wrightii roots. Appl. Environ. Microbiol. 43, 1244-1248.

Tamura K., Dudley J., Nei M., and Kumar S. (2007), MEGA4: Molecular evolutionary genetics analysis (MEGA) software version 4.0. Mol. Biol. Evol. 24, 1596-1599.

Tello E., Castellanos L., Arevalo-Ferro C., and Duque C. (2009), Cembranoid diterpenes from the Caribbean sea whip Eunicea knighti. J. Nat. Prod. 72, 1595-1602.

Thale Z., Johnson T., Tenney K., Wenzel P. J., Lobkovsky E., Clardy J., Media J., Pietraszkiewicz H., Valeriote F. A., and Crews P. (2002), Structures and cytotoxic properties of sponge-derived bisannulated acridines. J. Org. Chem. 67, 9384-9391.

Thompson F. L., Thompson C. C., Hoste B., Vandemeulebroecke K., Gullian M., and Swings J. (2003), Vibrio fortis sp. nov. and Vibrio hepatarius sp. nov., isolated from aquatic animals and the marine environment. Int. J. Syst. Evol. Microbiol. 53, 1495-1501.

Vacelet J. (1975), Etude en microscopie électronique de l'association entre bactéries et spongiaires du genre Verongia (Dictyoceratida) J. Microsc. Biol. Cell. 23, $271-288$.

Vairappan C. S. (2003), Potent antibacterial activity of halogenated metabolites from Malaysian red algae, Laurencia majuscula (Rhodomelaceae, Ceramiales). Biomol. Eng. 20, 255-259.

Yebra D. M., Kiil S., and Dam-Johansen K. (2004), Antifouling technology - past, present and future steps towards efficient and environmentally friendly antifouling coatings. Prog. Org. Coat. 50, 75-104.

Zhou M. H., Han F. F., Li J., and Zhao X. W. (2008), Isolation and identification of a novel alginate-degrading bacterium, Ochrobactrum sp. Songklanakarin. J. Sci. Technol. 30, 135-140. 